PIOTR CIŻKOWICZ, PAWEŁ OPALA,

ANDRZEJ RZOŃCA

\title{
ROLA SYSTEMU PODATKOWEGO PRZED, W TRAKCIE I PO KRYZYSIE FINANSOWYM
}

\section{WSTEP}

Globalny kryzys finansowy zapoczątkowany w 2008 r. wywarł istotny wpływ na stan finansów publicznych wielu krajów europejskich. W miarę przechodzenia przez kolejne fazy kryzysu i towarzyszące temu procesowi zmiany uwarunkowań gospodarczych zmieniały się również rekomendacje odnośnie do zestawu narzędzi polityki fiskalnej pozwalającego na optymalne wykorzystanie jej potencjału stabilizacyjnego. Początkowo w większości krajów rozwiniętych rekomendacje te zalecały wprowadzenie stymulacji fiskalnej o szerokim spektrum (to znaczy zarówno działań zwiększających wydatki publiczne, jak i obniżających podatki). Obecnie natomiast znaczna część tych samych krajów skłania się ku zacieśnieniu fiskalnemu, gdyż - przynajmniej w części z nich utrzymanie dotychczasowej luźnej polityki fiskalnej stwarzałoby realne ryzyko kryzysu fiskalnego.

Celem niniejszego artykułu jest podsumowanie najnowszych wyników badań analizujących rolę, jaką w kolejnych fazach kryzysu odegrał (lub odegra w najbliższej przyszłości) system podatkowy jako podstawowe narzędzie polityki fiskalnej. Przeprowadzona w opracowaniu analiza wskazuje, że jego rola ulegała istotnym zmianom w miarę zmian roli polityki fiskalnej:

- przed wybuchem kryzysu system podatkowy w wielu krajach stwarzał bodźce do takich zachowań podmiotów gospodarczych, które przyczyniały się do narastania nierównowagi leżącej u podstaw kryzysu;

- po wybuchu kryzysu wzrosło znaczenie stabilizacyjne systemu podatkowego: zarówno w obszarze oddziaływania tak zwanych automatycznych stabilizatorów, jak i dyskrecjonalnych zmian obciążeń podatkowych;

- natomiast obecnie zmiany systemu podatkowego zmierzaja w kierunku wsparcia procesu konsolidacji fiskalnej (poprzez wzrost obciążeń podatkowych i parapodatkowych) oczekiwanej w najbliższych latach w wielu gospodarkach rozwiniętych i w części krajów rozwijających się.

W kolejnych częściach artykułu (II-IV) omówiono rolę systemu podatkowego $\mathrm{w}$ tych trzech aspektach. W części V podsumowano główne wnioski z analizy. 


\section{WPLYW SYSTEMU PODATKOWEGO NA WYBUCH KRYZYSU W 2008 ROKU}

Kształt systemu podatkowego ma istotny wpływ na zachowania podmiotów gospodarczych oraz gospodarstw domowych. Nie zawsze jednak zachowania, do których skłania konstrukcja systemu, sa optymalne z gospodarczego punktu widzenia. Taką sytuację można było zaobserwować w latach poprzedzających kryzys gospodarczy z 2008 r. Jak wskazuje Międzynarodowy Fundusz Walutowy, niektóre cechy systemu podatkowego skłaniały przedsiębiorstwa i gospodarstwa domowe do zachowań, które choć nie były główną przyczyną kryzysu, to sprzyjały powstawaniu prowadzących do niego różnych typów nierównowagi ${ }^{1}$. Warto wskazać przynajmniej trzy z nich. Po pierwsze, ulgi i zwolnienia podatkowe dla nabywców nieruchomości mieszkaniowych pozwoliły zredukować koszt ich zakupu, co doprowadziło do nadmiernego wzrostu popytu i przyspieszonego narastania bańki cenowej na rynku mieszkaniowym. Po drugie, progresywny charakter podatków dochodowych $\mathrm{w}$ połączeniu z podatkowym uprzywilejowaniem alternatywnych form wynagradzania sprzyjał tworzeniu w przedsiębiorstwach skomplikowanych systemów płacowych, które skłaniały ich kadrę zarządzającą do podejmowania nadmiernego ryzyka biznesowego w celu osiągnięcia krótkookresowego wzrostu wyceny firmy i - w efekcie - swojego wynagrodzenia. Po trzecie, występujące w systemach podatkowych wielu krajów uprzywilejowanie finansowania dłużnego w stosunku do kapitałowego sprzyjało nadmiernemu zadłużaniu się przedsiębiorstw, co naraziło je na problemy płynnościowe po wybuchu kryzysu. Poniżej przedstawiono każdy z tych mechanizmów.

\section{System podatkowy a rynek mieszkaniowy}

W wielu krajach systemy podatkowe premiuja inwestowanie na rynku mieszkaniowym $\mathrm{w}$ stosunku do innych rodzajów inwestycji ${ }^{2}$. Zachowanie neutralności opodatkowania dochodu właściciela nieruchomości mieszkaniowych wymaga spełnienia przynajmniej dwóch warunków: pełnego opodatkowania tak zwanego czynszu kalkulacyjnego (imputed rents), a więc wartości usług mieszkaniowych konsumowanych przez właściciela nieruchomości, oraz pełnego opodatkowania zysków kapitałowych wynikających z posiadania nieruchomości ${ }^{3}$. Pierwszy warunek wynika z konieczności zrównania opodatkowania wartości konsumpcji usług mieszkaniowych, stanowiących dodatkowy dochód właściciela nieruchomości, z alternatywą w postaci opłacania czynszu finansowanego z dochodów pochodzących z opodatkowanych źródeł. Drugi-

\footnotetext{
${ }^{1}$ Debt Bias and Other Distortions: Crisis-Related Issues in Tax Policy, Międzynarodowy Fundusz Walutowy, 2009.

${ }^{2}$ Ekonomiczna analiza rynku mieszkaniowego została przedstawiona m.in. w: J. Kearl, Inflation, Mortgages, and Housing, „Journal of Political Economy” 87, 1979, nr 5; J. M. Poterba, Tax Subsidies to Owner-occupied Housing: An Asset-market Approach, ,Quarterly Journal of Economics” 99, 1984, nr 4; idem, House Price Dynamics: the Role of Tax Policy and Demography, „Brooking Papers on Economic Activity” 1991, nr 2; idem, Taxation and Housing: Old Questions, New Answers, „American Economic Review" 82, 1992, nr 2.

${ }^{3}$ Debt Bias and Other Distortions..., op. cit.
} 


\section{Wykres 1}

Efektywna stopa podatku dochodowego od nieruchomości w wybranych krajach*

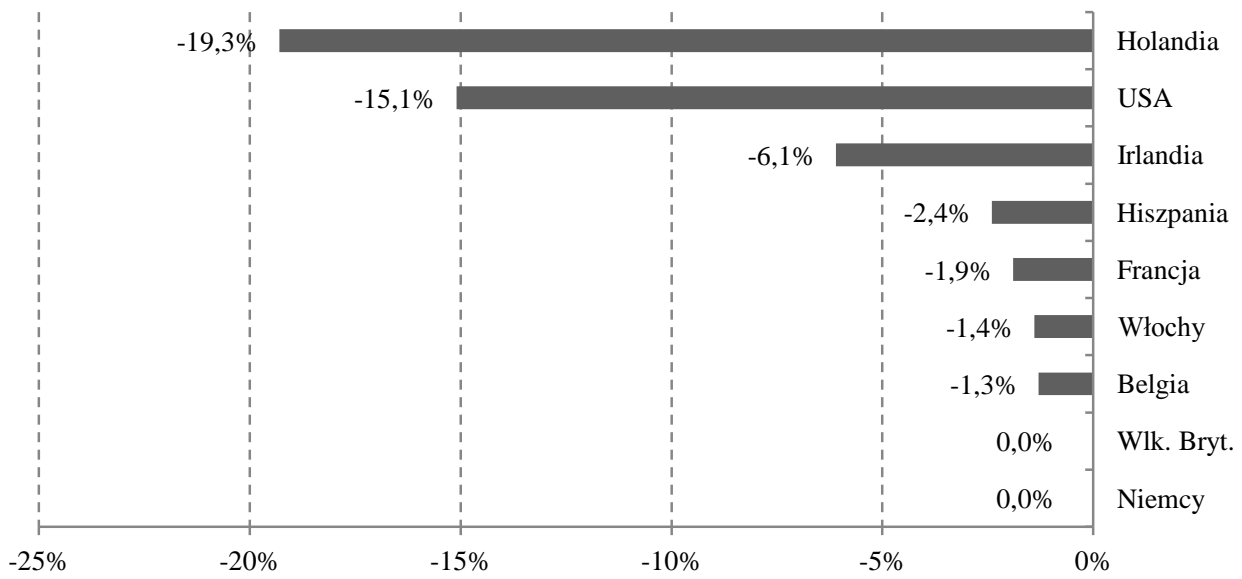

* Wyznaczona przy następujących założeniach: wartość nieruchomości: $500 \quad 000$ euro, stopa oprocentowania kredytu hipotecznego: $6 \%$ (oprocentowanie stałe), stopa dyskontowa: 5\%, inflacja cen mieszkań: 5\%, czynsz kalkulacyjny: 4\%, udział finansowania dłużnego: $80 \%$, maksymalna stawka podatku dochodowego w danym kraju.

Żródło: V. Ceriani, S. Manestra, G. Ricotti, A. Sanelli, E. Zangari, The Tax System and the Financial Crisis, „Questioni di Economia e Finanza”, nr 85, Banca d'Italia, 2011.

opodatkowanie zysków kapitałowych - wynika z tego, że zazwyczaj opodatkowane sa zyski osiagane $\mathrm{z}$ inwestycji w inne aktywa (na przykład zyski z inwestycji giełdowych lub dochody z lokat bankowych), mogące stanowić alternatywę dla inwestycji mieszkaniowych.

W praktyce powyższe warunki rzadko sa spełnione, co prowadzi do podatkowego faworyzowania posiadaczy nieruchomości mieszkaniowych ${ }^{4}$. Jedynie niewielka liczba krajów stosuje opodatkowanie czynszu kalkulacyjnego (na przykład Belgia i Holandia ${ }^{5}$ ). Podobnie w większości krajów istnieje wiele ograniczeń w opodatkowaniu zysków kapitałowych od nieruchomości.

Powyższe uwarunkowania sprawiaja, że efektywna stopa podatku dochodowego od nieruchomości, liczona jako relacja wartości bieżącej wszystkich podatków zapłaconych w okresie posiadania nieruchomości do wartości bieżącej wszystkich przychodów wynikających z jej posiadania (a więc czynszu kalkulacyjnego oraz zysków kapitałowych), jest w wielu krajach ujemna ${ }^{6}$. Wykres 1 przedstawia efektywną stopę podatku dochodowego od nieruchomości

${ }^{4}$ Dodatkowo w wielu krajach funkcjonują różne formy odliczenia od podatku dochodowego kosztów spłaty kredytu zaciagniętego na zakup nieruchomości mieszkaniowych.

${ }^{5}$ Więcej na ten temat można znaleźć w: T. Hemmelgarn, G. Nicodeme, E. Zangari, The Role of Housing Tax Provisions in the 2008 Financial Crisis, Taxation Papers, Office for Official Publications of the European Communities, Luksemburg 2011.

${ }^{6}$ Por. np. V. Ceriani, S. Manestra, G. Ricotti, A. Sanelli, E. Zangari, The Tax System and the Financial crisis, „Questioni di Economia e Finanza”, nr 85, Banca d'Italia, 2011. 
w wybranych krajach wysokorozwiniętych. Jak widać w niektórych z nich (na przykład w Holandii, Stanach Zjednoczonych), inwestycje w nieruchomości sa silnie subsydiowane przez system podatkowy. Ale nawet w krajach o efektywnej stopie podatkowej wynoszacej zero (na przykład w Niemczech czy w Wielkiej Brytanii) mamy do czynienia $\mathrm{z}$ faworyzowaniem inwestycji $\mathrm{w}$ nieruchomości, gdyż zazwyczaj w przypadku innych inwestycji efektywna stopa opodatkowania jest istotnie większa od zera ${ }^{7}$.

W efekcie charakterystyka systemu podatkowego w obszarze nieruchomości mieszkaniowych prowadzi - ceteris paribus - do zwiększenia popytu. Ponadto, jak wskazuje P. Van den Noord, cenowa elastyczność popytu na mieszkania jest odwrotnie proporcjonalna do stopnia faworyzowania rynku mieszkaniowego przez system podatkowy oraz do oczekiwanej stopy wzrostu cen mieszkań ${ }^{8}$. Oznacza to, że wzrost preferencji podatkowych dla rynku nieruchomości skutkuje większą zmiennością cen nieruchomości. Duża zmienność cen może natomiast prowadzić do nieoptymalnych decyzji podmiotów gospodarczych, a w skrajnym przypadku do powstawania baniek cenowych na rynku mieszkaniowym - zjawiska leżącego u podstaw kryzysu finansowego z $2008 \mathrm{r}$. Dodatkowo, możliwość odliczania od dochodu odsetek od kredytów zaciągniętych na zakup mieszkania lub domu może zwiększać skalę zadłużenia sektora gospodarstw domowych ponad poziom gwarantujący odporność na szoki zewnętrzne. Zjawisko bardzo szybkiego narastania zadłużenia gospodarstw domowych $\mathrm{z}$ tytułu kredytów mieszkaniowych rzeczywiście poprzedzało wystapienie kryzysu w wielu krajach.

\section{System podatkowy a wynagrodzenia kadry zarządzającej}

W wypadku kadry zarządzającej dużych przedsiębiorstw często praktykowane jest dzielenie wynagrodzenia na część gotówkową oraz udziałową, najczęściej w postaci opcji na akcje przedsiębiorstwa. Podstawowym motywem stosowania wynagrodzenia opartego na akcjach przedsiębiorstw jest występowanie tak zwanego problemu agencji, a więc sytuacji, w której prywatne cele kadry zarządzającej różnią się od celów przedsiębiorstwa. W założeniu taka forma wynagrodzenia powinna łączyć cele prywatne $\mathrm{z}$ celami firmy i tym samym lepiej motywować pracowników do działania w jej interesie ${ }^{9}$.

Zasady opodatkowania wynagrodzenia udziałowego są odmienne w różnych krajach, często jednak jest ono uprzywilejowane pod względem podatkowym w stosunku do wynagrodzeń gotówkowych. Jak wskazuje Międzynarodowy Fundusz Walutowy, w wielu krajach przy wynagrodzeniu w formie opcji na akcje opodatkowaniu podatkiem dochodowym podlega różnica pomiędzy cena rynkową i ceną wykonania opcji, umożliwiając odłożenie w czasie zapłaty części podatku ${ }^{10}$. Dodatkowo często skala uprzywilejowania tej formy wynagrodzenia

\footnotetext{
${ }^{7}$ Ibidem.

${ }^{8}$ P. Van den Noord, Tax Incentives and House Price Volatility in the Euro Area: Theory and Evidence, ,Économie Internationale” 101, 2005, nr 1.

${ }^{9}$ Por. np. The Taxation of Employee Stock Options, ,OECD Tax Policy Study”, nr 11, OECD, 2005.

${ }^{10}$ Debt Bias and Other Distortions..., op. cit.
} 
rośnie wraz z poziomem dochodów. Przykładowo, dla podatników o wysokich dochodach podatkowe uprzywilejowanie tej formy wynagrodzenia sięga nawet 58,5 punktów procentowych w Danii, 42,8 - w Hiszpanii, 30 - w Wielkiej Brytanii, 26,5 - we Francji oraz 22 - w Belgii ${ }^{11}$.

Badania empiryczne dotyczące korzyści podatkowych $\mathrm{z}$ wynagrodzeń opartych na opcjach na akcje przedsiębiorstw są jednak niejednoznaczne. Niektórzy badacze dowodzą, że korzyści z tej formy wynagrodzenia sa umiarkowane ${ }^{12}$, inni odnotowuja wręcz jej podatkowe defaworyzowanie ${ }^{13}$. Niekonkluzywność badań empirycznych może wynikać $\mathrm{z}$ różnic $\mathrm{w}$ podejściu stosowanym do oceny siły i kierunku wpływu systemu podatkowego w tym przypadku. Przykładowo, udziałowe systemy wynagrodzeń mogą być podatkowo korzystne dla jednej ze stron kontraktu (pracodawcy lub pracownika), nawet jeśli łącznie są one neutralne lub niekorzystne ${ }^{14}$. Taka sytuacja może często występować w dużych korporacjach, w których system wynagrodzeń kadry zarządzającej jest najczęściej tworzony przez nią samą, a nie przez akcjonariuszy, co w efekcie umożliwia przyjęcie zasad wynagrodzeń, które $\mathrm{z}$ punktu widzenia przedsiębiorstwa sa podatkowo niekorzystne ${ }^{15}$.

Jak wskazuje wskazany wyżej przykład, nawet jednostronne faworyzowanie podatkowe wynagrodzeń udziałowych stwarza dodatkowe - poza tradycyjnymi, związanymi z problemem agencji - bodźce do jego stosowania. Bodźce te prowadzą do nadużywania tej formy wynagradzania i nasilania się towarzyszących im niepożądanych zachowań, na przykład do tak zwanego zarządzania nakierowanego na zwiększanie własnych zarobków (earnings management), które skutkuje nadmierną ekspozycja przedsiębiorstwa na ryzyko ${ }^{16}$.

\section{System podatkowy a skala zadłużenia przedsiębiorstw}

Wpływ podatków na skalę zadłużenia przedsiębiorstw wynika z preferencyjnego traktowania przez system podatkowy finansowania przedsiębiorstw długiem względem finansowania kapitałem (tak zwany efekt debt-bias). Jeżeli w wielu krajach istnieje możliwość wyłączenia ze zobowiązań podatkowych kosztu finansowania długu (to znaczy odsetek od kredytów zaciagniętych przez przedsiębiorstwo), to w przypadku kosztu finansowania kapitałowego taka możliwość nie występuje.

Siła stwarzanych przez system podatkowy zachęt do finansowania dłużnego rośnie wraz ze wzrostem efektywnej stawki podatku dochodowego od osób prawnych. R. A. de Mooij na podstawie analizy wyników szeregu badań empi-

11 The Taxation of Employee..., op. cit.

${ }^{12}$ B. Hall, J. Liebman, The Taxation of Executive Compensation, 2000 w: V. Ceriani, S. Manestra, G. Ricotti, A. Sanelli, E. Zangari, op. cit.

${ }^{13}$ Por. np. H. Fehr, L. Knoll, L. Mikus, Taxation of Stock Options: An International Comparison, „Tax Notes International” 33, 2004, nr 5.

${ }^{14}$ V. Ceriani, S. Manestra, G. Ricotti, A. Sanelli, E. Zangari, op. cit.

${ }^{15}$ Por. np. Principles for Sound Compensation Practices, Financial Stability Forum, 2009; The Taxation of Employee..., op. cit.

${ }^{16}$ Por. np. E. Benmelech, E. Kandel, P. Veronesi, Stock-Based Compensation and CEO (Dis)Incentives, ,The Quarterly Journal of Economics” 125, 2010, nr 4. 


\section{Wykres 2}

Efektywna krańcowa stopa opodatkowania w wypadku finansowania kapitałowego i dłużnego w krajach Europy Środkowo-Wschodniej

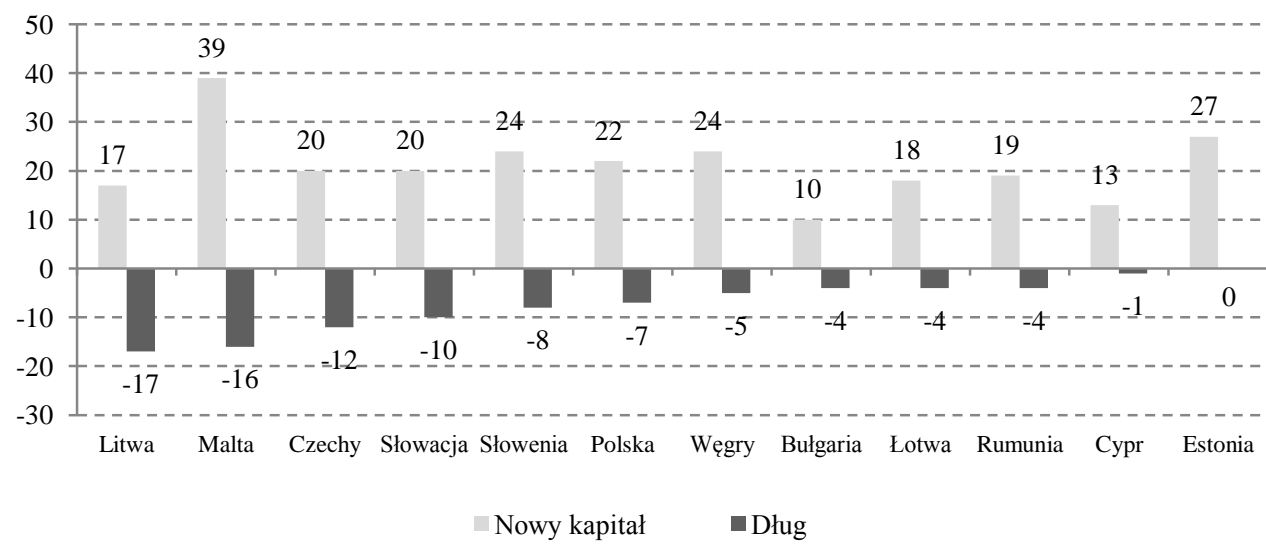

Źródło: Monitoring Tax Revenues and Tax Reforms in EU Member States 2010. Tax Policy after the Crisis, Taxation Papers, Working Paper nr 24, Komisja Europejska, 2010.

rycznych oszacował, że zwiększenie podatku dochodowego od osób prawnych o jeden punkt procentowy prowadzi do zwiększenia wskaźnika ogólnego zadłużenia (to jest relacji długu do aktywów przedsiębiorstwa) o $0,17-0,28^{17}$. Z badań tych wynika również, że siła wpływu podatków dochodowych od osób prawnych na skalę lewarowania przedsiębiorstw w ostatnich latach uległa zwiększeniu. Jednocześnie obciążenie w kierunku finansowania dłużnego jest tym większe, im lepsza jest kondycja finansowa przedsiębiorstwa, gdyż rośnie skala możliwych do uzyskania z tego tytułu korzyści. To z kolei może prowadzić do sytuacji, w której problem nadmiernego zadłużenia pojawia się również w firmach dobrze prosperujących.

Na siłę bodźców do finansowania dłużnego wpływają również zasady opodatkowania dochodów odsetkowych, dywidend i zysków kapitałowych ${ }^{18}$. W tym przypadku wpływ dotyczy atrakcyjności rodzajów finansowania przedsiębiorstwa postrzeganej przez inwestora: im wyższy podatek od dochodów odsetkowych, tym dla inwestora mniejsza jest korzyść z udzielania kredytu, większa zaś z zaangażowania kapitałowego w przedsiębiorstwo. W efekcie wraz ze wzrostem podatku od dochodów odsetkowych efekt debt-bias ulega zmniejszeniu, z punktu widzenia przedsiębiorstwa obniża się bowiem relatywny koszt finansowania kapitałem (oczekiwana przez inwestora stopa zwrotu z inwestycji

${ }^{17}$ R. A. de Mooij, The Tax Elasticity of Corporate Debt: A Synthesis of Size and Variations, IMF Working Paper WP/11/95, 2011.

${ }^{18}$ Debt Bias and Other Distortions..., op. cit. 
kapitałowej spada). Natomiast odwrotny wpływ ma skala opodatkowania dywidend oraz zysków kapitałowych: im jest większa, tym - ceteris paribus inwestycje kapitałowe stają się dla inwestora mniej atrakcyjne, wzrasta zatem koszt pozyskania finansowania przedsiębiorstwa tą droga.

W rezultacie efektywna krańcowa stopa opodatkowania różni się znacząco w zależności od metody finansowania. Jak pokazuje wykres 2, w krajach Europy Środkowo-Wschodniej jest ona istotnie większa od zera przy finansowaniu kapitałowym oraz ujemna lub zerowa przy finansowaniu dłużnym. Taka sytuacja sprzyja nadmiernemu zadłużaniu firm, co w sytuacji ograniczenia dostępności kredytu przez sektor finansowy, która miała miejsce po wybuchu kryzysu w 2008 r., skutkuje problemami z utrzymaniem płynności ${ }^{19}$.

\section{ROLA SYSTEMU PODATKOWEGO W TRAKCIE KRYZYSU FINANSOWEGO}

Jak wskazaliśmy $\mathrm{w}$ punkcie II, pewne charakterystyki systemu podatkowego mogą stwarzać bodźce do podejmowania przez podmioty gospodarcze działań, które przyczyniły się do wybuchu kryzysu finansowego w 2008 r. $\mathrm{Z}$ drugiej jednak strony, system podatkowy może odgrywać stabilizującą rolę $\mathrm{w}$ trakcie jego trwania, absorbując część negatywnego wstrząsu, jakiemu $\mathrm{w}$ kryzysie podlegają dochody podmiotów gospodarczych. Wpływ ten może odbywać się samoczynnie poprzez oddziaływania tak zwanych automatycznych stabilizatorów lub też wynikać $\mathrm{z}$ dyskrecjonalnych zmian $\mathrm{w}$ systemie podatkowym. W dalszej części niniejszego punktu omówimy zasady i efekty funkcjonowania automatycznych stabilizatorów oraz - odwołując się do koncepcji mnożników fiskalnych - przedstawimy czynniki decydujące o skuteczności dyskrecjonalnych zmian polityki fiskalnej w krótkookresowym stymulowaniu gospodarki.

\section{Automatyczne stabilizatory a skala kryzysu}

Automatyczne stabilizatory można zdefiniować jako te elementy polityki fiskalnej, które w sposób samoczynny, bez dyskrecjonalnej ingerencji władz, ograniczają skalę wahań produkcji ${ }^{20}$. Taki sposób ich funkcjonowania wynika $\mathrm{z}$ antycyklicznego charakteru: $\mathrm{w}$ okresie szybkiego wzrostu gospodarczego spowalniaja one tempo wzrostu popytu zagregowanego, a w czasie recesji zmniejszają skalę jego spadku. Dotyczy to zarówno elementów przychodowej (na przykład podatki), jak i wydatkowej (na przykład świadczenia społeczne) strony polityki fiskalnej. Klasycznym przykładem automatycznego stabilizatora sa progresywne podatki dochodowe. W okresie szybkiego wzrostu

\footnotetext{
19 T. Hemmelgarn, G. Nicodeme, The 2008 Financial Crisis and Taxation Policy, Taxation Papers, Komisja Europejska, 2010.

${ }^{20}$ A. J. Auerbach, D. Feenberg, The Significance of Federal Taxes as Automatic Stabilizers, ,,Journal of Economic Perspectives" 14, 2000, nr 3.
} 
gospodarczego progresywny podatek dochodowy ogranicza tempo wzrostu dochodu do dyspozycji, a tym samym hamuje tempo wzrostu popytu globalnego. W czasie recesji mamy do czynienia z sytuacją odwrotną. Warto podkreślić kilka ważnych cech automatycznych stabilizatorów ${ }^{21}$.

Po pierwsze, ich znaczenie zwiększa się wraz ze wzrostem roli państwa w gospodarce - wraz ze wzrostem relacji podatków i wydatków sektora finansów publicznych do PKB rośnie stabilizacyjna rola systemu podatkowego. Zależność ta ma jednak charakter nieliniowy: Debrun i inni oszacowali, że dla krajów OECD po przekroczeniu przez wydatki sektora finansów publicznych poziomu $40 \%$ PKB, dalszy wzrost wydatków o 1 punkt procentowy prowadzi do zmniejszenia zmienności produktu o mniej niż 0,1 punktu procentowego ${ }^{22}$. Wynika to z negatywnego wpływu nadmiernego udziału państwa w gospodarce na długookresowe tempo wzrostu gospodarczego ${ }^{23}$. Ten negatywny wpływ może istotnie przewyższać korzyści wynikające ze stabilizacyjnej roli systemu podatkowego ${ }^{24}$.

Oczywiście duże znaczenie dla siły wpływu automatycznych stabilizatorów ma sposób, w jaki są one wbudowane w system podatkowy. Na przykład M. G. Attinasi i inni zbadali wpływ podatku dochodowego od osób fizycznych na zmienność produkcji w krajach OECD w latach 1982-2009, stwierdzając, że im większa progresywność podatku dochodowego, tym mniejsze wahania produkcji ${ }^{25}$. Zatem wraz ze wzrostem progresywności podatku dochodowego rośnie jego skuteczność jako automatycznego stabilizatora ${ }^{26}$.

Po drugie, siła wpływu automatycznych stabilizatorów jest tym większa, im wyższa jest elastyczność dochodowa popytu gospodarstw domowych na towary i usługi i im bardziej trwały jest, w ich ocenie, spadek dochodów. Przykładowo, jeżeli gospodarstwa domowe oceniają, że szok dochodowy ma charakter przejściowy, a finansowanie zewnętrzne jest łatwo dostępne, to reakcja popytu na

\footnotetext{
${ }^{21}$ Pogłębioną analizę automatycznych stabilizatorów, jak również wyniki badań empirycznych poświęconych ocenie skutków ich funkcjonowania, można znaleźć m.in. w: J. Gali, Government Size and Macroeconomic Stability, „European Economic Review” 38, 1994, nr 1; A. Fatas, I. Mihov, Government Size and Automatic Stabilizers: International and Intranational Evidence, „Journal of International Economics" 55, 2001, nr 1; J. Andres, R. Domenech, Automatic Stabilizers, Fiscal Rules and Macroeconomic Stability, ,European Economic Review” 50, 2006, nr 6; J. Andres, R. Domenech, A. Fatas, The Stabilizing Role of Government Size, „Journal of Economic Dynamics and Control” 32, 2008, nr 2; M. A. Silgoner, G. Reitschuler, J. C. Cuaresma, On the Effectiveness and Limits of Fiscal Stabilizers, „Applied Economics” 43, 2011.

${ }^{22}$ X. Debrun, J. Pisani-Ferry, A. Sapir, Government Size and Output Volatility: Should We Forsake Automatic Stabilization, IMF Working Papers 8122, Międzynarodowy Fundusz Walutowy, 2008.

${ }^{23}$ Por. np. W. Leibfritz, J. Thornton, A. Bibbee, Taxation and Economic Performance, OECD Economics Department Working Papers, No. 176, OECD Publishing, 1997; Public Finances in EMU2010, European Economy" 2010, nr 4; Komisja Europejska, 2010.

${ }^{24}$ Por. np. T. Baunsgaard, S. A. Symansky, Automatic Fiscal Stabilizers: How Can They Be Enchanced without Increasing the Size of Government?, Międzynarodowy Fundusz Walutowy, SPN/09/23, 2009; X. Debrun, R. Kapoor, Fiscal Policy and Macroeconomic Stability: Automatic Stabilizers Work, Always and Everywhere, Międzynarodowy Fundusz Walutowy WP/10/111, 2010.

${ }^{25}$ M. G. Attinasi, C. Checherita-Westphal, M. Rieth, Personal Income Tax Progressivity and Output Volatility Evidence From OECD Countries, European Central Bank Working Paper Series, nr 1380, Europejski Bank Centralny, 2011.

${ }^{26}$ Jednakże, jak podkreślają T. Baunsgaard i S. A. Symansky, op. cit., efekt ten nie jest wystarczający do tego, by uzasadnić stratę PKB per capita wywołaną przez rosnąca progresywność podatku.
} 


\section{Wykres 3}

Skala absorpcji szoku dochodowego przez automatyczne stabilizatory w wybranych krajach OECD

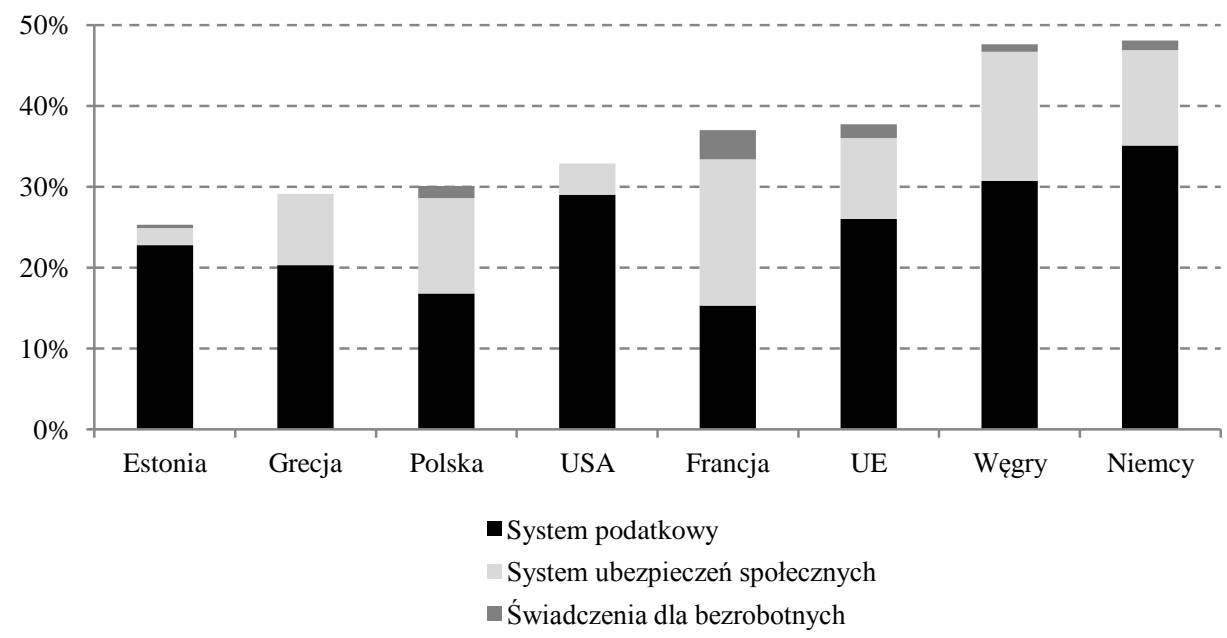

Źródło: M. Dolls, C. Fuest, A. Peichl, Automatic Stabilizers and Economic Crisis: US vs. Europe, Discussion Paper 4310, The Institute for the Study of Labor (IZA), Bonn, 2009.

szok będzie niewielka (ze względu na dążenie gospodarstw domowych do międzyokresowego wygładzania konsumpcji), a tym samym znaczenie automatycznych stabilizatorów będzie bliskie zeru ${ }^{27}$.

Po trzecie, automatyczne stabilizatory nie posiadaja dwóch zasadniczych wad dyskrecjonalnych metod stymulacji fiskalnej. W odniesieniu do automatycznych stabilizatorów nie występuje bowiem problem spóźnionej reakcji, co zazwyczaj ma miejsce w wypadku działań dyskrecjonalnych, ponadto ich działanie ulega ,,automatycznemu" odwróceniu w momencie zmiany sytuacji rynkowej ${ }^{28}$. Oznacza to, że wraz z poprawą sytuacji rynkowej automatyczne stabilizatory samoistnie zaczynają poprawiać stan finansów państwa. Do odwrócenia dyskrecjonalnej stymulacji fiskalnej potrzebna jest natomiast kolejna decyzja polityczna, co ze względu na różne ograniczenia (cykl polityczny, niechęć do podejmowania niepopularnych społecznie działań) zachodzi albo z opóźnieniem, albo wcale.

Skala absorpcji szoków przez automatyczne stabilizatory zależy więc od wielu czynników, stąd różni się istotnie pomiędzy poszczególnymi krajami. Odmienna jest również rola systemu podatkowego w łącznym oddziaływaniu automatycznych stabilizatorów. M. Dolls i inni oszacowali siłę wpływu automatycznych stabilizatorów w Unii Europejskiej i Stanach Zjednoczonych

\footnotetext{
${ }^{27}$ M. Dolls, C. Fuest, A. Peichl, Automatic Stabilizers and Economic Crisis: US vs. Europe, Discussion Paper 4310, The Institute for the Study of Labor (IZA), Bonn, 2009.

${ }^{28}$ Por. T. Baunsgaard, S. A. Symansky, op. cit.
} 
w czasie kryzysu finansowego z 2008 r. Symulacja dotyczyła dwóch rodzajów szoków: proporcjonalnego spadku dochodów brutto gospodarstw domowych o 5\% oraz wzrostu stopy bezrobocia o 5 punktów procentowych $\mathrm{W}$ pierwszym wypadku, automatyczne stabilizatory zabsorbowały ok. 38\% szoku w Unii Europejskiej oraz ok. 32\% w Stanach Zjednoczonych (wykres 3). W drugim absorpcja w Unii Europejskiej i Stanach Zjednoczonych wyniosła odpowiednio 48 i 34\%. Zgodnie $\mathrm{z}$ wynikami symulacji w Polsce siła absorpcji obu rodzajów szoków wyniosła ok. $30 \%{ }^{29}$.

\section{Mnożniki fiskalne a dyskrecjonalna polityka fiskalna}

Siłę oddziaływania dyskrecjonalnych zmian polityki fiskalnej na gospodarkę mierzą tak zwane mnożniki fiskalne, definiowane jako relacja zmiany popytu $\mathrm{w}$ reakcji na egzogeniczną zmianę deficytu fiskalnego ${ }^{30}$. Wartość tych mnożników zależy zarówno od szeregu czynników egzogenicznych w stosunku do impulsu fiskalnego, jak i endogenicznych (związanych z charakterystyka impulsu). Tabela 1 zawiera podsumowanie wpływu najważniejszych z nich na wartość mnożników.

Ze względu na przedstawione powyżej czynniki, wartości mnożników moga być silnie zróżnicowane. E. Ilzetzki i inni zauważyli na przykład, że są one wyższe w krajach rozwiniętych niż w krajach rozwijających się, a także wyższe w krajach o sztywnym kursie walutowym niż w krajach z płynnym kursem walutowym (gdzie ich wartość jest bliska zeru) ${ }^{31}$. R. J. Barro i C. J. Redlick na podstawie analizy szeregów czasowych dla Stanów Zjednoczonych od $1914 \mathrm{r}$. obliczyli, że wartość mnożnika towarzysząca tymczasowemu i trwałemu wzrostowi wydatków na obronę narodową wynosi, odpowiednio, ok. 0,5 i 0,6-0,7, zaś w wypadku zmiany przeciętnej krańcowej stopy podatku dochodowego ok. $1^{32}$. Szacunki mnożników fiskalnych dla grupy państw G-20 przedstawione przez Międzynarodowy Fundusz Walutowy wskazują na bardzo dużą rozbieżność ich wartości: 0,3-0,6 dla zmian podatkowych, 0,5-1,8 dla zmian wydatków inwestycyjnych oraz 0,3-1,0 dla pozostałych wydatków ${ }^{33}$.

Nie ma także zgody odnośnie do zmian poziomu mnożników fiskalnych w czasie, w szczególności ewentualnych różnic w ich poziomie między okresem kryzysu i boomu gospodarczego. A. Afonso i inni, na podstawie danych dla 127 krajów z lat 1981-2007, sprawdzili, czy mnożniki fiskalne ulegają zmianie w okresie kryzysów finansowych, na co wskazywałaby istotnie mniejsza dostępność finansowania zewnętrznego w takich okresach. Autorzy nie zaobserwowali jednak statystycznie istotnych różnic: zarówno $\mathrm{w}$ trakcie kryzysów finansowych, jak i w pozostałych latach mnożniki fiskalne związane

${ }^{29}$ M. Dolls, C. Fuest, A. Peichl, op. cit.

${ }^{30}$ A. Spilimbergo, S. Symansky, M. Schindler, Fiscal Multipliers, Międzynarodowy Fundusz Walutowy, 2009.

${ }^{31}$ E. Ilzetzki, E. G. Mendoza, C. A. Vegh, How Big (Small?) are Fiscal Multipliers?, NBER Working Paper nr 16479, 2010.

${ }^{32}$ R. J. Barro, C. J. Redlick, Macroeconomic Effects from Government Purchases and Taxes, NBER Working Paper nr 15369, 2010.

${ }^{33}$ Global Economic Policies and Prospects, Group of Twenty. Meeting of the Ministers and Central Bank Governors, Międzynarodowy Fundusz Walutowy, 2009. 
Tabela 1

Najważniejsze czynniki wpływające na wartość mnożników fiskalnych

\begin{tabular}{|c|c|c|}
\hline $\begin{array}{l}\text { Charakter } \\
\text { czynnika }\end{array}$ & Obszar wpływu & Rodzaj wpływu \\
\hline \multirow[t]{4}{*}{ Egzogeniczne } & $\begin{array}{l}\text { „Nieszczelności”, to zna- } \\
\text { czy skala stłumienia im- } \\
\text { pulsu fiskalnego przez } \\
\text { oszczędności lub wydatki } \\
\text { na dobra importowane }\end{array}$ & $\begin{array}{l}\text { Mnożniki fiskalne sa wyższe, gdy: } \\
\text { - wyższa jest krańcowa skłonność do kon- } \\
\text { sumpcji, } \\
\text { - wyższa część wydatków lub obniżek po- } \\
\text { datków trafia do gospodarstw domowych } \\
\text { w trudnej sytuacji finansowej, a więc o ogra- } \\
\text { niczonym dostępie do finansowania zew- } \\
\text { nętrznego, } \\
\text { - mniejszy jest stopień, w jakim gospodarstwa } \\
\text { domowe uwzględniaja w swoich bieżących } \\
\text { decyzjach konsumpcyjnych oczekiwania doty- } \\
\text { czące wzrostu przyszłych podatków w reakcji } \\
\text { na wzrost bieżącego deficytu, } \\
\text { - niższa jest importochłonność konsumpcji } \\
\text { i inwestycji. } \\
\text { Mnożniki fiskalne sa tym wyższe, im mniejsza } \\
\text { jest siła oddziaływania automatycznych sta- } \\
\text { bilizatorów*. }\end{array}$ \\
\hline & $\begin{array}{l}\text { Sposób prowadzenia poli- } \\
\text { tyki pieniężnej }\end{array}$ & $\begin{array}{l}\text { Mnożniki fiskalne sa wyższe, gdy polityka } \\
\text { pieniężna jest bardziej akomodacyjna, a więc } \\
\text { nominalne stopy procentowe nie sa } \\
\text { podnoszone w reakcji na efekty stymulacji } \\
\text { fiskalnej ani nie następuje aprecjacja kursu } \\
\text { walutowego. }\end{array}$ \\
\hline & Stan finansów publicznych & $\begin{array}{l}\text { Mnożniki fiskalne są tym niższe, im gorszy jest } \\
\text { stan finansów publicznych. W takich wypad- } \\
\text { kach bowiem reakcja na impuls fiskalny } \\
\text { i wynikający z niego wzrost długu publicznego } \\
\text { jest wzrost długookresowych stóp procen- } \\
\text { towych, co z kolei prowadzi do spadku kon- } \\
\text { sumpcji i inwestycji (efekt wypychania). }\end{array}$ \\
\hline & $\begin{array}{l}\text { Stopień rozwoju rynku } \\
\text { finansowego }\end{array}$ & $\begin{array}{l}\text { Im mniejsza jest dostępność zewnętrznego } \\
\text { finansowania, tym większy wpływ krótko- } \\
\text { okresowych wahań dochodu na bieżąca } \\
\text { konsumpcję i inwestycje, a w efekcie wyższy } \\
\text { mnożnik fiskalny. } \\
\text { Im słabiej rozwinięty jest rynek finansowy, } \\
\text { tym wyższy jest koszt finansowania rosnącego } \\
\text { deficytu i długu, a tym samym większy wzrost } \\
\text { stóp procentowych w wyniku impulsu fiskal- } \\
\text { nego. Wysokie stopy procentowe z kolei pro- } \\
\text { wadzą do efektu wypychania konsumpcji i in- } \\
\text { westycji, a tym samym do obniżenia mnożnika. }\end{array}$ \\
\hline
\end{tabular}

* Choć - jak podkreślają A. Spilimbergo, S. Symansky, M. Schindler, op. cit. - w czasie recesji automatyczne stabilizatory zwiększają siłę impulsu fiskalnego, tym samym rekompensując (częściowo lub w całości) efekt niższych mnożników. 
cd. tab. 1

\begin{tabular}{|l|l|l|}
\hline $\begin{array}{c}\text { Charakter } \\
\text { czynnika }\end{array}$ & \multicolumn{1}{|c|}{ Obszar wpływu } & \multicolumn{1}{c|}{ Rodzaj wpływu } \\
\hline Endogeniczne & $\begin{array}{l}\text { Charakter impulsu } \\
\text { fiskalnego }\end{array}$ & $\begin{array}{l}\text { W wypadku tymczasowych zmian fiskalnych } \\
\text { wyższymi mnożnikami charakteryzuja się } \\
\text { impulsy wpływające na ceny (na przykład } \\
\text { obniżka podatku VAT), natomiast w razie } \\
\text { zmian trwałych - wpływajace na dochód (na } \\
\text { przykład obniżka podatku dochodowego). }\end{array}$ \\
\cline { 2 - 3 } & Trwałość impulsu & \\
\hline
\end{tabular}

Źródło: opracowanie własne na podstawie A. Spilimbergo, S. Symansky, M. Schindler, op. cit. oraz E. Ilzetzki, E. G. Mendoza, C. A. Vegh, How Big (Small?) are Fiscal Multipliers?, NBER Working Paper nr 16479, 2010.

z impulsem o charakterze wydatkowym wyniosły w badanej próbie krajów ok. $0,6^{34}$. Odmienne wyniki uzyskali natomiast A. J. Auerbach i Y. Gorodnichenko, którzy na podstawie danych dla krajów OECD stwierdzili, że w czasie kryzysu finansowego mnożniki fiskalne wzrastaja ${ }^{35}$.

\section{CO PO KRYZYSIE? MOŻLIWE ZMIANY W SYSTEMACH PODATKOWYCH}

Swiatowy kryzys finansowy wywarł (i wywiera nadal) bardzo silny, negatywny wpływ na stan finansów publicznych w wielu krajach. Wynikało to zarówno z działania automatycznych stabilizatorów, jak i dyskrecjonalnych decyzji mających na celu stymulowanie gospodarki oraz dofinansowanie instytucji (głównie $\mathrm{z}$ sektora finansowego) narażonych na ryzyko bankructwa. W wielu krajach najważniejszym wyzwaniem dla polityki fiskalnej w najbliższych latach jest więc ustabilizowanie stanu finansów publicznych.

Jak szacuje Międzynarodowy Fundusz Walutowy (MFW), w 2011 r. dług sektora finansów publicznych w krajach rozwiniętych przekroczy $100 \% \mathrm{PKB}$, co oznacza wzrost o ok. 30 punktów procentowych w stosunku do okresu sprzed kryzysu finansowego ${ }^{36}$. Co więcej, według prognoz MFW w 2016 r., relacja długu sektora finansów publicznych do PKB w tej grupie krajów osiągnie blisko $110 \%$. W grupie krajów rozwijających się zadłużenie sektora finansów publicznych jest istotnie niższe - w 2011 r. szacowane jest na ok. $38 \%$ PKB, a do 2016 r. prognozowany jest jego spadek do $31 \%$.

Wraz z rosnącym długiem i utrzymującymi się wysokimi deficytami rosna potrzeby pożyczkowe, zwłaszcza w krajach wysokorozwiniętych. Całkowite potrzeby pożyczkowe w 2012 r. wyniosa 25\% PKB w krajach wysokoroz-

${ }^{34}$ A. Afonso., H. P. Gruner, C. Kolerus, Fiscal Policy and Growth. Do Financial Crises Make a Difference?, European Central Bank Working Paper Series 1217, Europejski Bank Centralny, 2010.

${ }^{35}$ A. J. Auerbach, Y. Gorodnichenko, Fiscal Multipliers in Recession and Expansion, NBER Working Paper nr 17447, 2011.

${ }^{36}$ Fiscal Monitor. September 2011. Addressing Fiscal Challenges to Reduce Economic Risks, Międzynarodowy Fundusz Walutowy, Wrzesień 2011. 


\section{Wykres 4}

Rentowność długoterminowych obligacji skarbowych (stan na 25 listopada 2011 r.)

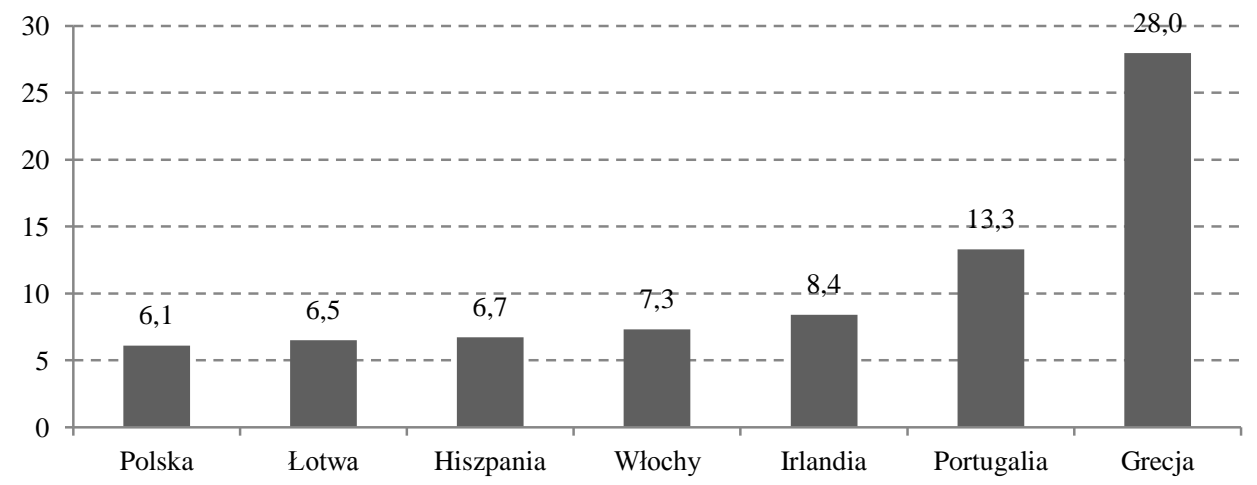

Źródło: Reuters Ecowin.

winiętych i 7,4\% PKB w krajach rozwijających się. W Stanach Zjednoczonych potrzeby pożyczkowe w 2012 r. sięgną 30,4\% PKB, w Japonii - aż 58,6\% PKB. W efekcie rosną koszty finansowania długu: już teraz rentowność obligacji $\mathrm{w}$ wielu krajach rozwiniętych jest wyższa niż w krajach rozwijających się (wykres 4), co w dużym stopniu można przypisać rosnącej premii za ryzyko wynikającej z dużych potrzebom pożyczkowych tych pierwszych.

Biorąc pod uwage obecną sytuację fiskalną większości krajów wysokorozwiniętych oraz znacznej części krajów rozwijających się, należy spodziewać się istotnego zacieśniania fiskalnego w nadchodzących latach. W dłuższej perspektywie konieczność zacieśniania, zwłaszcza w krajach wysokorozwiniętych, będzie dodatkowo wzmacniana negatywnymi konsekwencjami starzenia się społeczeństwa, w tym głównie koniecznością zwiększania wydatków emerytalnych i zdrowotnych ${ }^{37}$. Wykres 5 przedstawia skalę korekty fiskalnej, która jest niezbędna do tego, aby dług publiczny osiagnął do 2030 r. poziom $60 \%$ PKB w krajach wysokorozwiniętych oraz $40 \%$ PKB w krajach rozwijających się.

Powszechnie uważa się, że spodziewane zacieśnienie fiskalne będzie dotyczyło przede wszystkim istotnego ograniczenia skali wydatków publicznych. Nie do uniknięcia będzie jednak również zwiększenie obciążeń podatkowych, gdyż z jednej strony działania zmierzające do redukcji wydatków sektora finansów publicznych przynoszą zazwyczaj znaczące rezultaty $\mathrm{z}$ pewnym opóźnieniem ${ }^{38}$, z drugiej zaś skala możliwej konsolidacji po stronie wydatków

\footnotetext{
${ }^{37}$ Por. np. C. Cottarelli, A. Schaechter, Long-Term Trends in Public Finances in the G-7 Economies, IMF Staff Position Note, SPN/10/13, Międzynarodowy Fundusz Walutowy, 2010.

38 Pomijamy tutaj dostosowania wprowadzane w krajach znajdujących się na krawędzi niewypłacalności, jak np. znaczące i praktycznie natychmiastowe obniżenie nominalnego poziomu płac i emerytur w Grecji.
} 


\section{Wykres 5}

Skala korekty fiskalnej niezbędna do ustabilizowania długu sektora finansów publicznych w wybranych krajach



- Wymagana skala korekty fiskalnej w latach 2010-2020

- Wymagana korekta fiskalna oraz wydatki związane ze starzeniem się społeczeństwa w latach 2010-2030

Źródło: Fiscal Monitor. September 2011..., op. cit.

jest niewystarczająca do przywrócenia stabilności fiskalnej ${ }^{39}$. Międzynarodowy Fundusz Walutowy oszacował, jakie sa potencjalne możliwości zwiększenia dochodów podatkowych w wybranych krajach wysokorozwiniętych (tabela 2$)^{40}$. W obliczeniach przyjęto, że efektywna stawka podatku PIT i CIT nie ulegnie zwiększeniu. Zgodnie z obliczeniami największy wpływ na zwiększenie dochodów budżetowych miałoby uszczelnienie systemu podatkowego w obszarze podatku VAT, polegające na ograniczeniu wszystkich zwolnień i preferencyjnych stawek o połowę. Taka zmiana doprowadziłaby do zwiększenia dochodów podatkowych w relacji do PKB o ponad 3 punkty procentowe we Francji, Włoszech i Wielkiej Brytanii, oraz o 2,4 punktu procentowego w Niemczech. We Francji, Niemczech, Włoszech oraz Japonii istotny wpływ na poziom dochodów budżetu miałoby również zwiększenie podatku od nieruchomości do średniego poziomu (w relacji do PKB) notowanego w Stanach Zjednoczonych, Kanadzie i Wielkiej Brytanii. Relatywnie duży wzrost przyniosłoby również wprowadzenie pełnego aukcjoningu pozwoleń na emisję dwutlenku węgla lub ich opodatkowania (zob. niżej).

${ }^{39}$ Analizę potencjalnej skali zacieśnienia fiskalnego opartego na wydatkach, przeprowadzoną dla krajów G-20 można znaleźć w: C. Cottarelli, J. Viñals, A Strategy for Renormalizing Fiscal and Monetary Policies in Advanced Economies, IMF Staff Position Note SPN/09/22, Międzynarodowy Fundusz Walutowy, 2009.

${ }^{40}$ From Stimulus to Consolidation: Revenue and Expenditure Policies in Advanced and Emerging Economies, Międzynarodowy Fundusz Walutowy, 2010. 


\section{Tabela 2}

Szacunkowy, potencjalny wzrost dochodów budżetowych w wybranych krajach wysokorozwiniętych (w \% PKB)

\begin{tabular}{|l|c|c|c|c|c|}
\hline & $\begin{array}{c}\text { Uszczelnienie } \\
\text { podatku } \\
\text { VAT }^{\mathbf{1}}\end{array}$ & $\begin{array}{c}\text { Wzrost } \\
\text { przychodów } \\
\text { z opodatko- } \\
\text { wania } \\
\text { nierucho- } \\
\text { mości }^{\mathbf{2}}\end{array}$ & $\begin{array}{c}\text { Wzrost } \\
\text { akcyzy na } \\
\text { papierosy } \\
\text { i alkohol }^{\mathbf{3}}\end{array}$ & $\begin{array}{c}\text { Wzrost } \\
\text { akcyzy na } \\
\text { paliwo }\end{array}$ & $\begin{array}{c}\text { Pełny } \\
\text { aukcjoning } \\
\text { lub } \\
\text { opodatko- } \\
\text { wanie } \\
\text { emisji CO }_{\mathbf{2}}\end{array}$ \\
\hline Francja & 3,8 & 1,0 & 0,1 & 0,3 & 0,2 \\
Niemcy & 2,4 & 1,0 & 0,2 & 0,3 & 0,6 \\
Włochy & 3,1 & 1,0 & 0,3 & 0,3 & 0,5 \\
Japonia & 0,3 & 1,0 & 0,9 & 0,3 & 0,0 \\
Wlk. Brytania & 3,3 & 0,0 & 0,0 & 0,2 & 0,5 \\
USA & 0,0 & 0,0 & 0,3 & 0,6 & 0,8 \\
\hline
\end{tabular}

${ }^{1}$ Ograniczenie o połowę wyłączeń i preferencyjnych stawek podatku VAT.

${ }^{2}$ Wzrost udziału przychodów z podatku od nieruchomości w relacji do PKB do średniego poziomu z USA, Kanady i Wielkiej Brytanii.

${ }^{3}$ Wzrost akcyzy do średniego poziomu z 2006 r. w sześciu analizowanych krajach.

${ }^{4}$ Wzrost o 10 centów na litr.

Źródło: From Stimulus to Consolidation: Revenue and Expenditure Policies in Advanced and Emerging Economies, Międzynarodowy Fundusz Walutowy, 2010.

W dalszej części tego punktu skupiono się na analizie możliwości wynikających $\mathrm{z}$ trzech najszerzej dyskutowanych rozwiązań: poszerzenia bazy podatkowej dzięki ograniczeniu preferencji podatkowych, zwiększeniu dochodów budżetowych $\mathrm{z}$ tytułu obciążeń nakładanych na emitentów gazów cieplarnianych oraz dodatkowego opodatkowania sektora finansowego oraz transakcji kapitałowych ${ }^{41}$.

\section{Ograniczenie preferencji podatkowych}

Pierwsza ze wspomnianych powyżej grup planowanych zmian w systemach podatkowych dotyczy poszerzenia bazy podatkowej przez ograniczania preferencji podatkowych (tax expenditures). Stanowią one de facto utracone korzyści budżetowe wynikające ze stosowania różnego rodzaju odstępstw od obowiązujących stawek podatkowych (takich jak zwolnienia, odliczenia), czy też stosowanie stawek preferencyjnych. Jak podaje Ministerstwo Finansów, preferencje podatkowe maja w założeniu ,,skłonić beneficjenta preferencji do oczekiwanych przez państwo zachowań”, a „określone rozwiązania systemu podatkowego preferują w ten sposób pewne grupy podatników (np. rodziców, rolników, przedsiębiorców), sektor gospodarki (budownictwo, rolnictwo) lub działalność (np. inwestycje, innowacyjność, oszczędzanie)"42. Jednakże preferencje podatkowe maja również wiele wad. Jak wskazuje Bank Swiatowy ${ }^{43}$,

\footnotetext{
${ }^{41}$ Por. np. C. Cottarelli, A. Schaechter, op. cit.; Fiscal Monitor. September 2011..., op. cit.

${ }^{42}$ Preferencje podatkowe $w$ Polsce, Ministerstwo Finansów, Warszawa 2010, s. 12.
} 


\section{Tabela 3}

Różnice pomiędzy preferencjami podatkowymi a bezpośrednimi wydatkami budżetowymi

\begin{tabular}{|c|c|c|}
\hline & Preferencje podatkowe & Wydatki bezpośrednie \\
\hline Dostępność & $\begin{array}{l}\text { Łatwa ze względu na ich } \\
\text { automatyczny charakter. }\end{array}$ & $\begin{array}{l}\text { Bardziej skomplikowana, } \\
\text { wymaga selekcji benefi- } \\
\text { cjentów. }\end{array}$ \\
\hline Koszty administracyjne & $\begin{array}{l}\text { Wysokie w przypadku gdy } \\
\text { w sposób odpowiedni pro- } \\
\text { wadzony jest monitoring } \\
\text { preferencji. }\end{array}$ & $\begin{array}{l}\text { Średnie, ze względu na } \\
\text { konieczność selekcji i okre- } \\
\text { ślenia systemu alokacji. }\end{array}$ \\
\hline Możliwość nadużyć & $\begin{array}{l}\text { Uchylanie się, unikanie } \\
\text { i poszukiwanie renty. }\end{array}$ & $\begin{array}{l}\text { Arbitralność i nieefektyw- } \\
\text { ność. }\end{array}$ \\
\hline Przejrzystość i wiarogodność & Brak mechanizmów. & $\begin{array}{l}\text { Tak jak inne wydatki, } \\
\text { musza przejść proces ak- } \\
\text { ceptacji legislacyjnej. }\end{array}$ \\
\hline Kontrola skali wydatków & $\begin{array}{l}\text { Kontrola ex post, poziom } \\
\text { wydatków niepewny i po- } \\
\text { tencjalnie nieograniczony. }\end{array}$ & $\begin{array}{l}\text { Poziom wydatków kontro- } \\
\text { lowany i ograniczony re- } \\
\text { gulacjami. }\end{array}$ \\
\hline Równość & $\begin{array}{l}\text { Korzystaja wyłącznie osoby } \\
\text { płacące podatki, często naj- } \\
\text { większe korzyści odnosza } \\
\text { osoby o wysokich docho- } \\
\text { dach. }\end{array}$ & $\begin{array}{l}\text { Możliwe zapewnienie bar- } \\
\text { dziej równego dostępu po- } \\
\text { przez precyzyjne określenie } \\
\text { grupy beneficjentów. }\end{array}$ \\
\hline
\end{tabular}

Źródło: L. Villela, A. Lemgruber, M. Jorrat, Tax Expenditure Budgets, IDB Working Paper 179, 2010 za: Fiscal Monitor. April 2011. Shifting Gears. Tackling Challenges on the Road to Fiscal Adjustment, Międzynarodowy Fundusz Walutowy, Kwiecień 2011.

często sa one tworzone według błędnych założeń, w efekcie zachęcając do zachowań, które beneficjenci i tak by podjęli, niezależnie od stosowania preferencji. Ponadto zmniejszaja one bazę podatkowa, co oznacza, że aby utrzymać wpływy z danego rodzaju podatku na tym samym poziomie co bez preferencji, nominalne stawki podatku muszą być wyższe. Ze względu na fakt, że preferencje określaja jedynie warunki, jakie musi spełniać podmiot gospodarczy, nie jest znany z góry ich koszt dla budżetu, co utrudnia prognozowanie dochodów podatkowych. Przyczyniają się też do komplikacji prawa podatkowego, ograniczając jego przejrzystość i zwiększając koszty egzekwowania. W literaturze zwraca się uwagę na fakt, że efekty uzyskiwane za pomoca preferencji podatkowych można osiągnąc również bezpośrednimi wydatkami budżetowymi, nierzadko w bardziej efektywny sposób ${ }^{44}$. Najważniejsze różnice pomiędzy preferencjami podatkowymi oraz bezpośrednimi wydatkami przedstawia tabela 3 .

${ }^{43}$ Why Worry about Tax Expenditures?, World Bank Economic Policy 77. Bank Światowy, 2003.

${ }^{44}$ Por. L. Villela, A. Lemgruber, M. Jorrat, Tax Expenditure Budgets, IDB Working Paper nr 179, 2010 za: Fiscal Monitor. April 2011. Shifting Gears. Tackling Challenges on the Road to Fiscal Adjustment, Międzynarodowy Fundusz Walutowy, Kwiecień 2011. 


\section{Wykres 6}

Preferencje podatkowe w wybranych krajach w 2010 r. (w \% PKB)

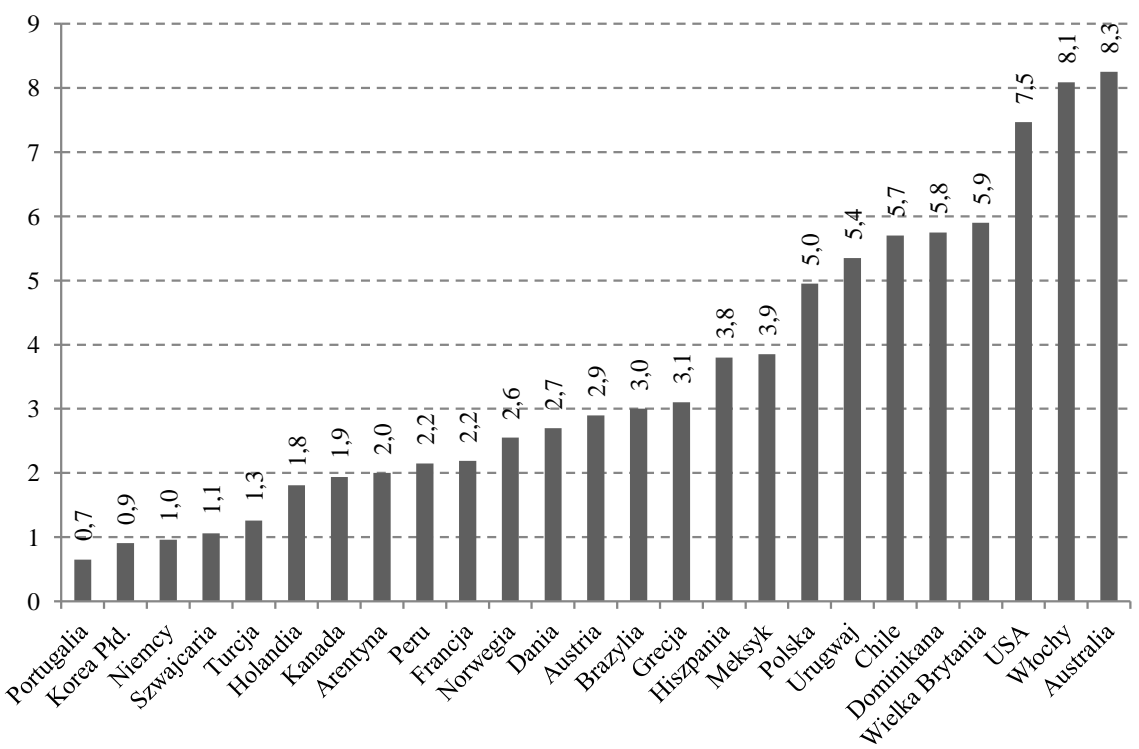

Źródło: Fiscal Monitor. April 2011. Shifting Gears. Tackling Challenges on the Road to Fiscal Adjustment, Międzynarodowy Fundusz Walutowy, Kwiecień 2011.

Warto podkreślić, że w niektórych krajach skala preferencji podatkowych jest bardzo duża, stąd potencjał do zwiększenia dochodów podatkowych dzięki ich ograniczeniu jest wysoki. W 2010 r. preferencje podatkowe wyniosły $5,0 \%$ PKB w Polsce, 5,9\% PKB w Wielkiej Brytanii, 7,5\% PKB w Stanach Zjednoczonych, 8,1\% PKB we Włoszech i 8,3\% PKB w Australii (wykres 6).

\section{Wpływy z obciążeń nakładanych na emitentów gazów cieplarnianych}

Duże znaczenie w kontekście poszukiwania nowych źródeł dochodów budżetowych $\mathrm{w}$ najbliższych latach moga mieć obciążenia nakładane na emitentów gazów cieplarnianych. Instrumentem, który będzie przynosić coraz większe wpływy budżetowe z tego tytułu, jest funkcjonujacy od 2005 r. Europejski System Handlu Emisjami (EU-ETS - European Union Emission Trading Scheme). Jest to system typu cap-and-trade, wprowadzający odgórny dopuszczalny limit emisji dwutlenku węgla na obszarze Unii (cap) oraz system handlu uprawnieniami do emisji w ramach tego limitu (trade). W początkowej fazie funkcjonowania systemu (do 2008 r.) kraje członkowskie Unii Europejskiej na podstawie danych historycznych o emisjach dwutlenku węgla przekazywały instalacjom co najmniej 95\% posiadanych uprawnień za darmo. Następnie operatorzy instalacji, w zależności od potrzeb, mogli wykorzystać posiadane 


\section{Wykres 7}

Szacunek przychodów ze sprzedaży uprawnień do emisji dwutlenku węgla w krajach Europy Środkowo-Wschodniej w latach 2013-2020

(w \% bieżącego poziomu długu sektora finansów publicznych)

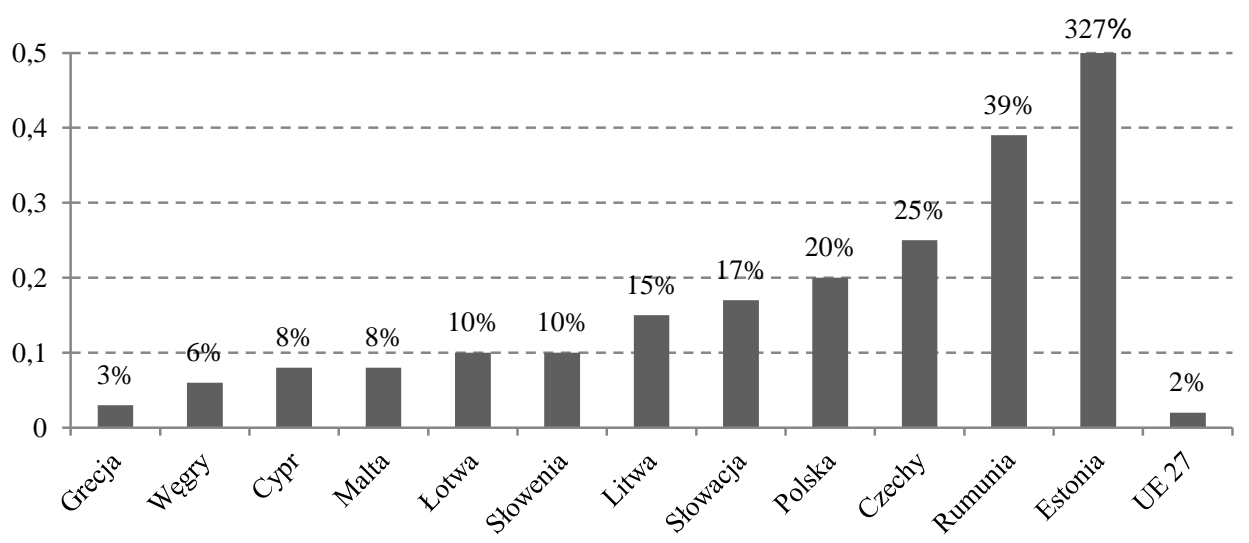

Źródło: obliczenia własne.

uprawnienia w procesie produkcji emitującej dwutlenek węgla albo sprzedać nadwyżkę uprawnień na rynku wtórnym. Podobne zasady obowiązują również w drugim okresie funkcjonowania EU-ETS (lata 2008-2012), z tym że obecnie kraje zobowiązane sa do przekazywania za darmo nieco mniejszej puli posiadanych uprawnień (co najmniej 90\%). Istotne zmiany planowane sa w trzecim okresie funkcjonowania EU-ETS, a więc w latach 2013-2020. Wtedy też, co do zasady, państwa członkowskie Unii Europejskiej nie będą mogły przydzielać uprawnień za darmo, a jedynie sprzedawać je na aukcjach (tak zwany aukcjoning). Trzeba podkreślić, że dla niektórych krajów przychody z tego tytułu moga być znaczne. Według ostrożnych szacunków wartość przychodów ze sprzedaży uprawnień do emisji dwutlenku węgla w latach 2013-2020 wyniesie ok. 2\% obecnego łącznego długu sektora finansów publicznych krajów Unii Europejskiej. Ale już na przykład na Węgrzech będzie to ok. 6\%, w Polsce - 20\%, a w Estonii - ponad 320\% (wykres 7).

\section{Dodatkowe opodatkowanie sektora finansowego}

Coraz częściej pojawiają się też głosy mówiące o konieczności dodatkowego opodatkowania sektora finansowego. Jedna z propozycji jest wprowadzenie podatku od transakcji kapitałowych, który miałby, przynajmniej w założeniu, realizować trzy funkcje ${ }^{45}$. Po pierwsze, dzięki zwiększeniu kosztów trans-

${ }^{45}$ Należy podkreślić, że nie są to propozycje nowe. Jak zauważają T. Hemmelgarn i G. Nicodeme, op. cit., propozycję opodatkowania transakcji kapitałowych w celu ograniczania skali spekulacji przedstawiał już w 1936 r. J. M. Keynes. Z kolei J. Tobin opowiadał się za opodatkowaniem transakcji 
akcyjnych i związanym z tym ograniczeniem spekulacji przyczyniłby się do zwiększenia stabilności rynków finansowych. Po drugie, pozwoliłby istotnie zwiększyć dochody podatkowe bez generowania nadmiernych zaburzeń $\mathrm{w}$ gospodarce. Po trzecie, pozwoliłby na przynajmniej częściowe odzyskanie środków, które zostały przeznaczone na ratowanie instytucji finansowych ${ }^{46}$. Jak szacuje Międzynarodowy Fundusz Walutowy, w grupie ośmiu krajów wysokorozwiniętych pomoc dla sektora finansowego udzielona ze środków publicznych osiągnęła od początku kryzysu wartość ok. 6,8\% PKB, z czego jak dotąd udało się odzyskać jedynie $1,8 \% \mathrm{PKB}^{47}$.

Propozycję wprowadzenia takiego podatku na terenie Unii Europejskiej ogłosiła Komisja Europejska, zakładając, że miałby on obowiązywać od $2014 \mathrm{r}$. i dotyczyć wszystkich transakcji na instrumentach finansowych, w których przynajmniej jedna strona transakcji zlokalizowana jest na terenie Unii. Komisja Europejska szacuje, że przychody z podatku wyniosłyby ok. 57 miliardów euro rocznie ${ }^{48}$.

Podatek od transakcji kapitałowych nie jest jednak pozbawiony wad ${ }^{49}$. Po pierwsze, istnieje ryzyko, że spadek liczby transakcji wywołany wzrostem kosztów doprowadzi do ograniczenia funkcji arbitrażowej rynku kapitałowego, prowadząc do większej zmienności cen. Po drugie, instytucje finansowe moga koszty związane z podatkiem przenieść na inne sektory gospodarki. Po trzecie, poziom skomplikowania niektórych transakcji kapitałowych jest tak duży, że trudno jest dokładnie przewidzieć wszystkie konsekwencje wprowadzenia podatku. Po czwarte, istnieje ryzyko, że część transakcji kapitałowych będzie przenoszona do krajów, w których podatek od transakcji kapitałowych nie zostanie wprowadzony.

Istotną wadą podatku od transakcji kapitałowych jest to, że nie ogranicza on problemu nadmiernego ryzyka podejmowanego przez instytucje finansowe ${ }^{50}$. Przed 2008 r. największe na świecie instytucje finansowe były postrzegane jako instytucje zbyt duże, by mogły upaść (too big to fail), co można było odczytywać jako niepisaną (i darmową) gwarancję ze strony państwa w wypadku ewentualnych problemów finansowych. Skutkowało to $-\mathrm{z}$ jednej strony obniżeniem kosztów finansowania zewnętrznego dla tych instytucji, z drugiej sprzyjało podejmowaniu przez nie nadmiernego ryzyka ${ }^{51}$. W celu ograniczenia skutków tego mechanizmu Międzynarodowy Fundusz Walutowy zaproponował alternatywne rozwiązanie: stworzenie tak zwanego wkładu finansowego na rzecz stabilności (Financial Stability Contribution), finansowanego podatkiem nakładanym na zobowiązania instytucji finansowych (pomniejszone między

\footnotetext{
walutowych typu spot, co miałoby ograniczyć ryzyka związane $\mathrm{z}$ nadmierną mobilnością kapitału i zwiększyć efektywność krajowej polityki monetarnej.

${ }^{46}$ T. Hemmelgarn i G. Nicodeme, op. cit.

${ }^{47}$ Fiscal Monitor. September 2011..., op. cit.

${ }^{48}$ Proposal for a Council Directive on a Common System of Financial Transaction Tax and Amending Directive 2008/7/EC, COM(2011) 594, 2011/0261 (CNS), Komisja Europejska 2011.

${ }^{49}$ Por. Financial Sector Taxation, Taxation Papers, Working Paper No. 25, Komisja Europejska, 2010.

${ }^{50}$ Ibidem.

${ }^{51}$ Por. np. Fiscal Monitor. November 2010. Fiscal Exit: From Strategy to Implementation, Międzynarodowy Fundusz Walutowy, listopad 2010.
} 
innymi o ubezpieczone depozyty i kapitał podstawowy). W założeniu stawka podatku miałaby być uzależniona od oceny ryzyka systemowego danej instytucji. Ponadto, MFW rekomenduje wprowadzenie dodatkowego podatku, tak zwany FAT (Financial Activities Tax) nakładanego na wynagrodzenia i zyski instytucji finansowych ${ }^{52}$.

\section{PODSUMOWANIE}

Z przeprowadzonej w niniejszym artykule analizy można wyciągnąć następujące wnioski:

Niektóre cechy systemu podatkowego skłaniały przedsiębiorstwa i gospodarstwa domowe do zachowań, które choć nie były główną przyczyną ogólnoświatowego kryzysu finansowego zapoczątkowanego w 2008 r., to sprzyjały powstawaniu prowadzącej do niego nierównowagi:

- po pierwsze, ulgi i zwolnienia podatkowe dla nabywców nieruchomości mieszkaniowych pozwoliły zredukować koszt ich zakupu, czym doprowadziły do nadmiernego wzrostu popytu i przyspieszonego narastania bańki cenowej na rynku mieszkaniowym;

- po drugie, progresywny charakter podatków dochodowych w połączeniu z podatkowym uprzywilejowaniem alternatywnych form wynagradzania sprzyjał tworzeniu w przedsiębiorstwach skomplikowanych systemów płacowych, skłaniających ich kadrę zarządzająca do podejmowania nadmiernego ryzyka biznesowego w celu osiągnięcia krótkookresowego wzrostu wyceny firmy $\mathrm{i}$ - w efekcie - swojego wynagrodzenia;

- po trzecie, występujące w systemach podatkowych wielu krajów uprzywilejowanie finansowania dłużnego $\mathrm{w}$ stosunku do kapitałowego sprzyjało nadmiernemu zadłużaniu się przedsiębiorstw, po wybuchu kryzysu naraziło je na problemy płynnościowe.

Po wybuchu kryzysu system podatkowy wspierał (krótkookresowo) stabilizacje gospodarcza poprzez oddziaływanie automatycznych stabilizatorów, takich jak progresywny podatek dochodowy oraz wprowadzanie dyskrecjonalnych zmian w wymiarze nakładanych obciążeń podatkowych. Wnioski z przeanalizowanych badań wskazuja na pewną rolę systemu podatkowego w absorpcji szoków gospodarczych, jednak siła tego oddziaływania zależy od wielu czynników i nie jest precyzyjnie określona.

Obserwowane w ostatnich latach narastanie nierównowagi fiskalnej w wielu krajach (w szczególności rozwiniętych) wymaga podjęcia zdecydowanej konsolidacji fiskalnej. Ponieważ w większości wypadków ograniczanie wydatków publicznych nie stwarza możliwości wprowadzenia zacieśnienia fiskalnego w skali gwarantującej stabilizację długu publicznego, konieczne będzie zwiększenie obciążeń fiskalnych. Najbardziej prawdopodobne kierunki ich wzrostu to:

${ }^{52}$ S. Claessens, M. Keen, C. Pazarbasioglu, Financial Sector Taxation: The IMF's Report to the G-20 and Background Material, Międzynarodowy Fundusz Walutowy, 2010. 
- poszerzenie bazy podatkowej poprzez eliminację preferencji podatkowych,

- zwiększenie obciążeń nakładanych na emitentów gazów cieplarnianych,

- obłożenie dodatkami podatkami sektora finansowego.

dr Piotr Ciżkowicz

Szkoła Gtówna Handlowa w Warszawie

mgr Pawet Opala

Szkota Gtówna Handlowa w Warszawie

dr Andrzej Rzońca

Szkoła Gtówna Handlowa w Warszawie

\title{
THE ROLE OF A TAXATION SYSTEM BEFORE, DURING AND AFTER A FINANCIAL CRISIS
}

\author{
Summary
}

The aim of this paper is to sum up the most recent results of a survey carried out to analyse the role which the system of taxation played in subsequent phases of the financial crisis that started in 2008. As can be seen from the obtained data that role has been substantially changing: (1) prior to the crisis the tax incentives that the system made available to business entities gave rise to even greater economic imbalance which later became one of the elements that laid the basis for the crisis; (2) when the crisis started, the stabilisation role of the taxation system prevailed and operated through the working of so called automatic stabilisers as well as through discretionary changes of tax burdens; and (3) currently, the taxation system is being modified to support the process of fiscal consolidation expected to be implemented in the coming years in the economies of developed and some developing countries. 
